\title{
PERANAN DISIPLIN KERJA DAN KESELAMATAN \& KESEHATAN KERJA (K3) DALAM MENINGKATKAN KINERJA KARYAWAN
}

\author{
Muhammad Faishal, B Lena Nuryanti S \& M. Masharyono \\ Universitas Pendidikan Indonesia \\ muhammad.faisha195@student.upi.edu
}

\begin{abstract}
The crisis of employee performance is a critical problem raised by management within the company. The company's financial problems are still a lot of complexity by companies in various sectors in the country, both engaged in the public and private sectors, in the fields of health, education, banking, state-owned companies, to small companies. Low competency and inaccessible to work targets because of the low quality of human resources. Performance is a real work carried out by every employee must be in accordance with their role in the company, which means that the quality of employee performance and work results are less than satisfactory and the low creativity of employees. This happened at PT XYZ company where the level of employee performance decreases every year. Surely this is far from the expectations of companies that ask their employees to have good performance. This study discusses research on work coordination and occupational safety \& health ( $k 3$ ) on employee performance This research uses quantitative methods involving 45 respondents using saturated samples with data collection techniques using questionnaires. The data analysis technique used is descriptive analysis. The results of this study indicate that the picture of work discipline in the high category, the picture of occupational safety and health ( $k 3)$ in the category is quite high and the description of employee performance in the high category.
\end{abstract}

Keywords: work discipline, occupational safety \& health ( $k 3$ ), employee performance

Abstrak: Krisisnya kinerja karyawan adalah masalah kritis yang diajukan oleh manajemen dalam perusahaan. Permasalahan keuangan perusahaan masih banyak kerumitan oleh perusahaan di berbagai sektor di negara, baik bergerak di sektor publik maupun swasta, di bidang kesehatan, pendidikan, perbankan, perusahaan milik negara, hingga perusahaan kecil. Kompetensi rendah dan tidak dapat diakses target kerja karena rendahnya kualitas sumber daya manusia. Kinerja merupakan kerja nyata yang dilakukan oleh setiap karyawan harus sesuai dengan perannya dalam perusahaan, yang berarti kinerja karyawan yang berkualitas dan hasil kerja yang kurang memuaskan dan rendahnya kreativitas karyawan. Hal ini terjadi pada perusahaan PT XYZ di mana tingkat kinerja karyawan menurun pada setiap tahunnya. Tentunya hal ini jauh dari harapan perusahaan yang meminta para karyawannya memiliki kinerja yang baik. Penelitian ini membahas tentang penelitian tentang koordinasi kerja dan keselamatan \& kesehatan kerja (k3) terhadap kinerja karyawan Penelitian ini menggunakan metode kuantitatif dengan melibatkan 45 responden menggunakan sampel jenuh dengan teknik pengumpulan data menggunakan kuisioner. Teknik analisis data yang digunakan adalah analisis deskriptif. Hasil penelitian ini menunjukkan bahwa gambaran disiplin kerja dalam kategori tinggi, gambaran keselamatan dan kesehatan kerja (k3) dalam kategori cukup tinggi dan gambaran kinerja karyawan dalam kategori tinggi.

Kata kunci: disiplin kerja, keselamatan \& kesehatan kerja (k3), kinerja karyawan

\section{PENDAHULUAN}

Masalah sumber daya manusia saat ini masih tetap menjadi pusat perhatian bagi suatu perusahaan untuk bertahan di era globalisasi dalam menghadapi Masyarakat Ekonomi ASEAN (MEA) perusahaan dituntut untuk melakukan persaingan usaha yang lebih kompetitif baik dengan pasar dalam negeri maupun luar negeri (Ayu, Sujana, \& Zukhri, 2017:70). Organisasi tanpa sumber daya manusia yang baik dalam hal strategi dan operasi tidak akan dapat mempertahankan dan mencapai tujuan organisasi (Nuryanti, Masharyono, \& Fauziatunisa, 2019).

Sumber daya manusia merupakan aset terpenting dalam organisasi, karena berperan dalam mencapai organisasi objektif . Sumber daya manusia adalah faktor dinamis maju yang mampu menentukan atau menarik suatu organisasi, sehingga instansi dengan sumber daya manusia yang handal dapat memenangkan persaingan (Senen, Sumiyati, \& Masharyono, 2016). Sumber daya manusia tetap menjadi satu bagian penting dalam sebuah perusahaan atau organisasi, oleh karena itu sumber daya manusia diperhatikan dengan seksama (Masharyono \& Senen, 2015).

Karyawan yang bekerja sesuai dengan kemampuan dan sesuai dengan posisinya relatif akan bekerja dengan baik. Apabila kinerja individu baik maka kinerja perusahaanpun akan baik. Kinerja karyawan merupakan sesuatu yang sangat penting 
dalam upaya organisasi untuk mencapai tujuannya. (Senen et al., 2016).

Masalah kinerja masih menjadi topik permasalahan dalam peneltian MSDM seperti yang dilakukan oleh Bolanle Odunlami dan Oludele Matthew (2014:115) mengenai kinerja karyawan di industri manufaktur menyatakan bahwa karyawan merupakan bagian yang tidak dapat terpisahkan dari manajemen sumber daya manusia. Krisisnya kinerja karyawan adalah masalah kritis yang dihadapi oleh manajemen dalam perusahaan.Permasalahan kinerja karyawan masih banyak dihadapi oleh perusahaan di berbagai sektor di banyak negara, baik bergerak di sektor publik maupun swasta, di institusi kesehatan, pendidikan, perbankan, perusahaan milik negara, sampai perusahaan kecil, maka memaksimalkan kinerja karyawan. Jadilah tantangan besar bagi setiap organisasi untuk dapat menggunakan sumber daya yang ada dengan lebih efisien dan efektif untuk mempertahankan daya saing (Senen \& Triananda, 2016).

Salah satu sektor publik yang mengalami masalah kinerja yaitu Badan Usaha Milik Negara (BUMN), merupakan suatu badan milik pemerintah yang ikut bersaing dunia usaha. Berdasarkan jenisnya, perusahaan BUMN dapat dikategorikan menjadi Perusahaan Perseroan (Persero), Perusahaan Umum (Perum), dan Perusahaan Jawatan (Perjan), walaupun bentuk Perjan kemudian ditiadakan. Setiap perusahaan BUMN akan berusaha untuk mencapai tujuan pendirian BUMN berdasarkan UU Nomor 19 tahun 2003 yaitu "Menjadi BUMN yang profesional untuk meningkatkan nilai BUMN". Salah satu faktor penting keberhasilan BUMN dalam mencapai tujuannya adalah sumber daya manusia berkualitas dan pengelolaan sumber daya manusia yang baik agar memperoleh kinerja yang optimal.

Sarana transportasi adalah salah satu hal yang sangat penting dalam memperlancar keberhasilan pembangunan perkembangan wilayah yang dapat menunjang segala kegiatan ekonomi yang dilakukan oleh masyarakat. Berkat adanya sarana transportasi, masyarakat mendapatkan kemudahan akses dalam mendapatkan segala kebutuhan hidup sehari-hari, serta mampu untuk meningkatkan kehidupan sosial dan ekonomi masyarakat (S \& Panjaitan, 2016:273).

Rendahnya intensitas dan tidak dapat diaksesnya target kerja karena rendahnya kualitas kinerja sumber daya manusia. Kinerja merupakan perilaku nyata yang ditunjukkan oleh setiap karyawan harus sesuai dengan perannya dalam perusahaan, bahwa dampak rendahnya kinerja karyawan adalah kualitas dan kuantitas pekerjaan yang dihasilkan kurang memuaskan dan rendahnya kreativitas karyawan (Nuryanti \& Rahmawati, 2016).
Masalah yang sering muncul dalam perusahaan saat ini adalah kurangnya perhatian terhadap aspek manusiawi. Bila ingin memahami perilaku karyawan, seorang manajer atau pimpinan harus dapat menciptakan kondisi-kondisi yang mendukung karyawan dan kegairahan kerja, sehingga dengan kondisi tersebut karyawan dapat meningkatkan mutu kerjanya sehingga sekaligus dapat meningkatkan kuantitas perusahaan itu sendiri (Ismail, 2016).

Rendahnya kinerja karyawan masih menjadi isu utama dalam pengelolaan sumber daya manusia. Kinerja karyawan menjadi sangat penting untuk terus ditingkatkan agar organisasi dapat mencapai tujuan. Karyawan berkinerja rendah merupakan prioritas yang dihadapi perusahaan saat ini, sehingga memaksimalkan kinerja menjadi tantangan utama suatu organisasi (Senen \& Triananda, 2016).

Seorang karyawan yang memiliki kinerja tinggi dan baik dapat menunjang tercapainya tujuan dan sasaran yang telah ditetapkan oleh perusahaan. Sebaliknya tujuan perusahaan susah atau bahkan tidak dapat tercapai bila karyawannya bekerja tidak memiliki kinerja yang baik sehingga tidak dapat menghasilkan kerja yang baik pula (Wairooy, 2017).

Pengukuran kinerja (performance measurement) diperlukan untuk dapat mengetahui sejauh mana keberadaan, peran, dan kontribusi sumber daya manusia dalam mencapai keberhasilan organisasi. Tanpa adanya evaluasi atau pengukuran kinerja dalam mencapai tujuan organisasi, maka tidak dapat diketahui penyebab ataupun kendala-kendala kegagalan organisasi dalam mencapai tujuan (Putri et al., 2013).

Faktor sumber daya manusia memegang peran yang paling penting dan utama dalam proses produksi karena alat produksi tidak akan berjalan tanpa dukungan dan keberadaan sumber daya manusia (Ismail, 2016).

Kinerja perusahaan dikatakan berkualitas dan berhasil dalam mencapai tujuan dapat dipengaruhi oleh faktor-faktor yang berasal dari dalam perusahaan seperti disiplin kerja, pendidikan dan pelatihan (diklat) karyawan sesuai dengan kemampuan karyawan dalam menyelesaikan tugas dan tanggung jawabnya, sehingga menghasilkan output yang berkualitas (Suardi, Anton, \& Suharsil, 2014). Disiplin kerja sangat penting karena dengan karyawan yang mempunyai disiplin kerja maka akan menghasilkan kualitas kerja, kuantitas kerja dan waktu kerja yang baik sehingga dapat meningkatkan kinerja karyawan (Wairooy, 2017).

Berdasarkan penelitian yang dilakukan oleh (Muogbo, 2013) pada industri manufaktur, disimpulkan bahwa kinerja karyawan relatif rendah ditandai dengan meningkatnya absensi karyawan, tetapi masih ada cara untuk memperbaikinya. Pencapaian kinerja karyawan dapat melalui penilaian disiplin kerja karyawan. Disiplin kerja sebagai suatu sikap kesediaan dan 
kerelaan seseorang untuk mematuhi dan mentaati norma-norma peraturan yang berlaku disekitarnya (Ayu et al., 2017).

Kedisiplinan karyawan mutlak diperlukan agar seluruh aktivitas yang sedang dan akan dilaksanakan berjalan sesuai mekanisme yang telah ditentukan. Kedisiplinan kerja akan mendorong karyawan agar tidak akan melakukan tindakan-tindakan yang dapat merugikan perusahaan (Mang, Mariani, \& Sariyathi, 2017).

Meningkatkan disiplin kerja karyawan perlu adanya fasilitas kerja yang baik. Fasilitas kerja merupakan suatu bentuk pelayanan perusahaan terhadap karyawan agar menunjang kinerja dalam memenuhi kebutuhan karyawan, sehingga dapat meningkatkan produktifitas kerja karyawan (Ismail, 2016).

Adanya faktor-faktor yang mempengaruhi kinerja antara lain: kompensasi, lingkungan kerja, budaya kerja, motivasi, disiplin kerja, kemampuan kerja dan K3 (Putri et al., 2013).

Winaryo \& Sunaryo (2016) menyebutkan bahwa kinerja karyawan dipengaruhi oleh faktor intrinsik dan ektrinsik karyawan. Faktor-faktor intrinsik yang mempengaruhi kinerja karyawan terdiri dari pendidikan, pengalaman, motivasi, kesehatan, usia, keterampilan, emosi dan spritual. Sedangkan faktor ektrinsik yang mempengaruhi kinerja karyawan terdiri dari lingkungan fisik dan non fisik, kepemimpinan, komunikasi vertikal dan horizontal, kompensasi, fasilitas, pelatihan, beban kerja, prosedur kerja, sistem hukuman dan sebagainya.

Berdasarkan peneltian yang dilakukan oleh Heryati \& Menzata (2018:71) salah satu cara dalam meningkatkan kinerja karyawan berupaya melakukan keselamatan operasional transportasi dalam mewujudkan operasional transportasi menuju nihil kecelakaan (zero accident). Pengelolaan keselamatan transportasi perlu dilakukan dengan sistematis dan berkelanjutan. Permasalahan kurangnya program diklat pemahaman K3 yang dilaksanakan pada suatu perusahaan mempengaruhi penilaian kinerja keselamatan operasional transportasi dalam laju penurunan frekuensi kecelakaan atau peristiwa luar biasa hebat (PLH) dari waktu ke waktu.

Berdasarkan hasil catatan Ditjen Perkeretaapian Kementerian Perhubungan di luar faktor eksternal, faktor penyebab kecelakaan kereta api didominasi oleh human error operator dengan persentase $25 \%$ disusul faktor sarana $24 \%$, prasarana $15 \%$, dan alam $7 \%$. Faktor human error pada kecelakaan kereta api sering dianggap kesalahan hanya masinis saja, namun perlu investigasi lebih mendalam karena human error yang terjadi merupakan kontribusi dari aspek lain seperti manajemen, sistem, dan lainnya (Budiawan, Sriyanto, Purwanggono, \& Tauhida, 2017)
Program keselamatan dan kesehatan kerja sebaiknya dimulai dari tahap yang paling dasar, yaitu pembentukan budaya keselamatan dan kesehatan kerja. Program keselamatan dan kesehatan kerja dapat berfungsi dan efektif, apabila program tersebut dapat terkomunikasikan kepada seluruh lapisan individu (S \& Panjaitan, 2016).

Ketika karyawan merasa terjamin keselamatan dan kesehatan kerja dan disertai dengan pemberian insentif maka ekspektasi terhadap karyawan agar bekerja seoptimal mungkin sangat tinggi. Sedangkan Insentif seringkali diartikan sebagai penggerak atau pendorong yang diberikan dengan sengaja kepada para pekerja, agar dalam diri mereka timbul semangat yang lebih besar untuk berprestasi. Insentif sebagai perangsang agar supaya para karyawan bekerja dengan penuh tanggung jawab sehingga kinerja karyawan dapat tercapai (Munandar, Astuti, \& Hakam, 2014)..

Keselamatan dan kesehatan kerja termasuk salah satu program pemeliharaan yang ada di perusahaan. Pelaksanaan program keselamatan dan kesehatan kerja bagi karyawan sangatlah penting karena bertujuan untuk menciptakan sistem keselamatan dan kesehatan kerja dengan melibatkan unsur manajemen, tenaga kerja, kondisi dan lingkungan kerja yang terintegrasi dalam rangka mengurangi kecelakaan (Juniarti \& Halin, 2017).

Perkembangan perusahaan sangat tergantung pada kinerja karyawan yang dimilikinya. Apabila dapat memelihara dan menjaga seluruh karyawannya dengan baik. Melalui program K3 yang baik diharapkan dapat menurunkan tingkat kecelakaan kerja dan mampu meningkatkan kinerja karyawan, sehingga prestasi kerjanya meningkat yang tercermin dari peningkatan pelayanan kepada pelanggan dan masyarakat. Dengan adanya program K3 konflik-konflik antara karyawan dengan perusahaan tentang jaminan keselamatan karyawan dapat diatasi, karena karyawan beranggapan bahwa perusahaan akan memikirkan keselamatan mereka saat bekerja.

Berdasarkan rumusan masalah di atas, maka tujuan penelitian ini adalah untuk memperoleh hasil temuan mengenai: (1) Bagaimana tingkat disiplin kerja (2) Bagaimana pelaksanaan K3 (Keselamatan dan Kesehatan, Kerja) (3) Bagaimana tingkat kinerja karyawan (4) Adakah pengaruh disiplin kerja terhadap kinerja karyawan (5) Adakah pengaruh K3 (Keselamatan dan Kesehatan, Kerja) terhadap kinerja karyawan (6) Adakah pengaruh disiplin kerja dan keselamatan \& kesehatan kerja (k3) terhadap kinerja karyawan.

\section{KAJIAN PUSTAKA}

Wayne Mondy \& Joseph (2016) manajemen sumber daya manusia (MSDM) adalah penggunaan individu untuk mencapai tujuan organisasi. Pada 
dasarnya, semua manajer menyelesaikan sesuatu melalui usaha orang lain. Akibatnya, manajer di setiap level harus memperhatikan MSDM. Individu yang menangani masalah sumber daya manusia menghadapi banyak tantangan, mulai dari tenaga kerja yang terus berubah sampai peraturan pemerintah yang selalu ada, revolusi teknologi, dan dunia.

Menurut Aryono (2016:9) sumber daya manusia adalah aset yang paling penting dalam sebuah perusahaan atau organisasi. Karyawan dapat menjadi potensial jika dikelola dengan baik dan benar, tapi akan menjadi beban jika tidak dikelola dengan benar. Kualitas sumber daya manusia akan menjadi kekuatan bagi manajemen dan mendukung kinerja suatu perusahaan atau organisasi untuk mencapai tujuan yang baik.

Menurut Wayne Mondy \& Joseph (2016) Orang yang terlibat dalam pengelolaan SDM berkembang dan bekerja melalui sistem manajemen sumber daya manusia terpadu. Ada enam area fungsional dikaitkan dengan manajemen sumber daya manusaia yang efektif diantaranya: 1) Staffing (Karyawan), 2) Performance management (Manajemen kinerja), 3) Human resource development (Pengembangan sumber daya manusia), 4) Compensation (Kompensasi), 5) Employee and labor relations (Hubungan karyawan dan tenaga kerja), 6) Sefty and healty (Keselamatan dan kesehatan).

Wayne Mondy \& Joseph (2016) Employee and labor relations (Hubungan karyawan dan tenaga kerja) terdiri dari kegiatan manajemen sumber daya manusia (MSDM) yang terkait dengan pergerakan karyawan di dalam perusahaan dan hubungan antara karyawan dan pengusaha di dalam perusahaan. Topik seperti itu meliputi tindakan disiplin, penghentian, penurunan pangkat, perampingan, mutasi, promosi, pengunduran diri, dan masa pensiun.

Wayne Mondy \& Joseph (2016) Mengemukakan bahwa disiplin adalah keadaan pengendalian diri karyawan dan perilaku tertib yang menunjukkan tingkat kerja sama tim dalam suatu organisasi. Aspek hubungan kerja internal yang perlu namun sering dicoba adalah penerapan tindakan disipliner, yang meminta penalti terhadap karyawan yang gagal memenuhi standar yang telah ditetapkan.

Edi Sutrisno (2017:96) mengemukakan dimensi disiplin kerja adalah sebagai berikut : (1) Taat terhadap aturan waktu : Dilihat dari jam masuk kerja, jam pulang, dan jam istirahat yang tepat waktu sesuai dengan aturan yang berlaku di perusahaan (2) Taat terhadap peraturan perusahaan: Peraturan dasar tentang cara berpakaian, dan bertingkah laku dalam pekerjaan (4) Taat terhadap aturan perilaku dalam pekerjaan: Ditunjukan dengan cara-cara melakukan pekerjaanpekerjaan sesuai dengan jabatan, tugas dan tanggung jawab serta cara berhubungan dengan unit kerja lain (4) Taat terhadap peraturan lainnya diperusahaan: Aturan tentang apa yang boleh dan apa yang tidak boleh dilakukan oleh para pegawai dalam perusahaan.

Menurut Wayne Mondy \& Joseph (2016) keselamatan melibatkan melindungi karyawan dari cedera akibat kecelakaan kerja. Kesehatan mengacu pada kebebasan karyawan dari penyakit fisik atau emosional. Aspek pekerjaan ini penting karena karyawan yang bekerja di lingkungan yang aman dan menikmati kesehatan yang baik lebih cenderung produktif dan menghasilkan keuntungan jangka panjang bagi organisasi.

Wayne Mondy \& Joseph (2016) mendefinisikan Keselamatan dan Kesehatan Kerja sebagai kondisi dan faktor yang mempengaruhi atau akan mempengaruhi keselamatan dan kesehatan pekerja (termasuk pekerja kontrak), tamu atau orang lain di tempat kerja.Wayne Mondy \& Joseph (2016) Bahwa dimensi keselamatan dan kesehatan kerja meliputi: Ergonomi yaitu Proses perancangan tempat kerja untuk menunjang kemampuan orang dan pekerjaan atau tuntutan tugas.

Menurut Widodo (2015:133) faktor yang mempengaruhi kinerja diantaranya: (1) Kualitas dan kemampuan pegawai: yaitu hal-hal yang berhubungan dengan pendidikan/ pelatihan, etos kerja, motivasi kerja, sikap mental, dan kondisi fisik pegawai (2) Sarana pendukung: yaitu hal yang berhubungan dengan lingkungan kerja (keselamatan kerja, kesehatan kerja, sarana produksi, teknologi) dan hal-hal yang berhubungan dengan kesejahteraan pegawai (upah/gaji, jaminan sosial, keamanan kerja) (3) Supra sarana: yaitu hal-hal yang berhubungan dengan kebijakan- kebijakan pemerintah dan hubungan industrial manajemen.

Menurut Wayne Mondy \& Joseph (2016) dimensi kinerja yaitu diantaranya: 1) kualitas kerja, 2) kuantitas kerja, 3) kerjasama, 4) inisiatif, 5) tanggung

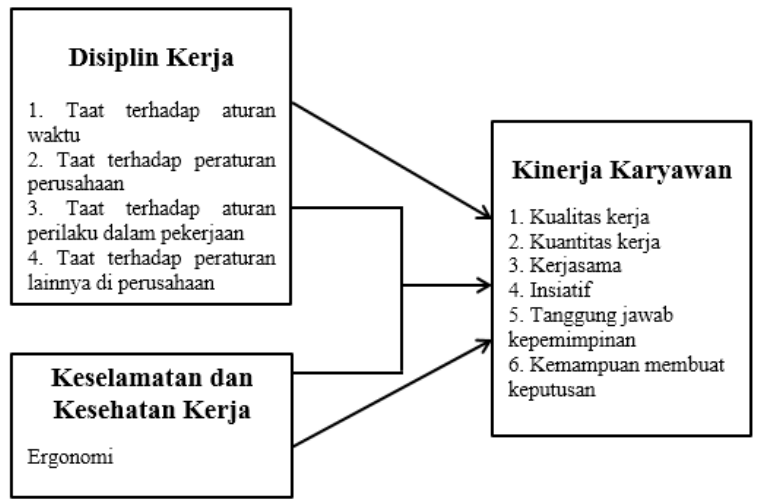

jawab kepemimpinan, 6) kemampuan membuat keputusan.

\section{GAMBAR 2.1 PARADIGMA PENELITIAN}

\section{METODE PENELITIAN}


Penelitian ini menggunakan pendekatan manajemen sumber daya manusia menganalisis pengaruh disiplin kerja dan keselamatan kesehatan kerja terhadap kinerja karyawan. Independent variabel atau variabel bebas yaitu disiplin kerja dan Keselamatan kesehatan kerja yang memiliki indikator. Sedangkan masalah penelitian yang menjadi dependent variabel atau variabel terikat adalah kinerja karyawan yang memiliki dimensi.

Adapun yang menjadi objek penelitian sebagai variabel $\mathrm{X}$ atau variabel bebas (independent variabel) adalah disiplin kerja (X1) dengan indikatornnya 1) taat terhadap aturan waktu, 2) taat terhadap peraturan perusahaan, 3) taat terhadap peraturan perilaku dalam perusahaan, dan 4) taat terhadap peraturan lainnya di perusahaan. Serta keselamatan dan kesehatan kerja (X2) dengan indikatornya yang mencakup 1) Ergonomi. Masalah penelitian yang merupakan variabel Y atau variabel terikat (dependent variable) adalah kinerja karyawan yang dimensinya mencakup 1) kualitas kerja, 2) kuantitas kerja, 3) kerjasama, 4) inisiatif, 5) tanggung jawab kepemimpinan, 6) kemampuan membuat keputusan.

Menurut Sugiyono (2017:7) jenis penelitian yang digunakan berdasarkan variabel-varibel yang diteliti, maka penelitian yang dilakukan bersifat deskriptif dan verifikatif. Penelitian deskriptif dalam penelitian ini ditujukan untuk mengetahui secara keseluruhan mengenai disiplin kerja, keselamatan dan kesehatan kerja. Menurut Sugiyono, (2017:7) mengungkapkan bahwa metode penelitian deskriptif merupakan penelitian yang dilakukan untuk menggambarkan variabel mandiri, baik hanya pada satu variabel atau lebih (variabel yang berdiri sendiri) tanpa membuat perbandingan dan mencari variable itu dengan variabel lain. Tujuan dari penelitian deskriptif adalah membuat deskripsi, gambaran atau lukisan secara sistematis, faktual dan akurat, mengatasi fakta-fakta, sifat-sifat, serta hubungan antara fenomena yang diselidiki. Penelitian deskriptif ini mempunyai maksud mengetahui gambaran secara keseluruhan mengenai gambaran disiplin kerja, gambaran keselamatan \& kesehatan kerja (k3), gambaran kinerja karyawan.

Berdasarkan jenis penelitian deskriptif yang dilaksanakan melalui pengumpulan data di lapangan, maka metode yang digunakan dalam penelitian ini adalah kuantitatif untuk mendapatkan informasi mengenai disiplin kerja, Keselamatan dan kesehatan kerja terhadap kinerja karyawan

\section{HASIL DAN PEMBAHASAN}

Variabel disiplin kerja terdiri dari empat dimensi dan tiga puluh empat indikator, diantaranya yaitu dimensi taat terhadap aturan waktu dari indikator ketepatan waktu bekerja, kemangkiran kerja, pulang kerja tanpa izin atasan, kesesuaian waktu Istirahat, penyalahgunaan waktu kerja, melakukan check in pada waktu masuk kerja, datang ditempat kerja sebelum jam kerja, menggunakan waktu istirahat dengan tepat, sistem pendataan kehadiran. Dimensi taat terhadap peraturan perusahaan dari indikator SOP (Standar Operasional Prosedur), Ketepatan menyelesaikan tugas, sopan santun, teguran, menggunakan/melalui pintu yang telah ditentukan untuk masuk atau keluar kompleks perusahaan, mengabaikan kewajiban. Dimensi taat terhadap aturan perilaku dalam pekerjaan dari indikator ketaatan terhadap bertingkah laku dalam bekerja, Mengabaikan tugas, kejujuran dalam bekerja, kesesuaian pekerjaan, kemampuan menggunakan alatalat perusahaan, perizinan, kemampuan merawat alat kerja, merasa keberatan jika harus selalu taat dan patuh kepada atasan, memiliki Etika dalam bekerja, memiliki kemampuan berkomunikatif, mengutamakan kepentingan pekerjaan. Dimensi terhadap peraturan lainnya dari indikator kepatuhan terhadap perintah atasan, cuti tahunan, istirahat panjang, pencemaran nama baik, kemampuan Menyimpan rahasia perusahaan, kemampuan memeliharaan tempat kerja, mengikuti breafing sebelum melakukan pekerjaan, membuat isu-isu yang dapat menimbulkan terjadinya keresahan, penggunaan barang-barang milik perusahaan.

Berdasarkan hasil penelitian dari angket yang disebar kepada 45 responden dapat diketahui bahwa disiplin kerja mencapai skor 13860 dari skor kriterium atau jumlah maksimal. Perolehan nilai responden teretak pada daerah sedang yaitu interval 1980-13860, aspek disiplin kerja kerja paling tinggi yaitu terdapat pada dimensi Taat terhadap aturan perilaku dalam pekerjaan memperoleh skor sebanyak 3284 atau $80 \%$, sementara dimensi paling rendah yaitu pada Taat terhadap peraturan perusahaan memperoleh skor 1790 atau $81 \%$. Variabel keselamatan dan kesehatan kerja terdiri dari satu dimensi dan empat indikator yaitu dimensi ergonomi dari indikator fisik, kognitif, organisasi, lingkungan.

Berdasarkan hasil penelitian dari angket yang disebar kepada 45 responden diketahui bahwa keselamatan dan kesehatan kerja karyawan Pt Kereta Api Indonesia (Persero) Daop 2 Bandung mencapai skor 3229 dari skor kriterium atau jumlah maksimal perolehan nilai responden terletak pada daerah efektif yaitu pada interval 675-4725, sehingga dapat dikatakan bahwa dalam penelitian ini keselamatan dan kesehatn kerja yang dimiliki oleh karyawan Pt Kereta Api Indonesia (Persero) Daop 2 Bandung telah diaplikasikan dengan cukup baik, namun kepuasan kerja karyawan perlu ditingkatkan lagi karena semua dimensi berada dibawah skor ideal.

Aspek keselamatan dan kesehatan kerja pada dimensi ergonomi memperoleh skor sebanyak 3229 
atau $68 \%$. Secara keseluruhan variabel keselamatan dan kesehatan kerja memperoleh skor 3229, apabila di persentasekan kedalam skor ideal maka diperoleh persentase sebesar $68 \%$, dapat dikatakan menurut Moch. Ali (2013:184) bahwa hampir seluruh responden menyatakan keselamatan dan kesehatan kerja dalam kategori tinggi.

Variabel kinerja karyawan terdiri dari enam dimensi dan enam puluh dua indikator, diantaranya dimensi kualitas kerja dari indikator mengutamakan kualitas dari pekerjaan yang dikerjakan, teliti dalam mengerjakan pekerjaan, antusias dalam bekerja, dukungan dari atasan, mengerjakan pekerjaan sesuai dengan aturan, keterampilan karyawan dalam bekerja, karyawan lebih mengutamakan mutu pekerjaan, loyalitas kerja, pengetahuan dan keahlian, ketenangan dalam bekerja, ketepatan dan kebenaran laporan pekerjaan, ketepatan menggunakan bahan/ perlengkapan kerja, kebenaran hasil pekerjaan. Dimensi kuantitas kerja dari indikator hasil kerja karyawan sesuai dengan target, hasil kerja melebihi target yang telah ditentukan, kemampuan menyelesaikan pekerjaan, melaksanakan tugas tepat waktu, kesesuaian aspek detail dan akurasi, menangani pekerjaan, kesanggupan bekerja diluar jam kerja, desain kerja, situasi kerja, kepercayaan diri, persentase hasil kerja. Dimensi inisiatif dari indikator kesadaran melaksanakan tugas, intesitas berdiskusi dalam hal pekerjaan, karyawan selalu bisa dalam menyelesaikan masalah pekerjaan, bekerja secara mandiri, kesediaan dalam menerima tugas, penggunaan teknologi, memiliki inisiatif dalam bekerja, kemampuan mengontrol diri, bekerja sesuai dengan waktu yang ditentukan perusahaan, ide dan gagasan dalam bekerja. Dimensi kerjasama dari indikator kekompakan, menghargai hasil kerja, kesediaan melakukan tugas sesuai kesepakatan, memberikan ide dan pendapat kepada rekan kerja, menciptakan suasana kerjasama yang akrab dalam bekerja, memiliki sikap mendorong rekan untuk bekerja sama, memberi penjelasan tentang pekerjaan dengan baik, bekerja sesuai dengan instruksi atasan, karyawan mampu bekerja sama dengan baik terhadap rekan kerja yang lain.Dimensi tanggung jawab kepemimpinan dari indikator bertindak adil dan tegas, memberikan bimbingan, memberikan contoh yang baik dalam bekerja, karyawan bertanggung jawab atas pekerjannya, karyawan dapat menjaga sikap untuk nama baik perusahaan, karyawan dapat melaksanakan pekerjaan dengan baik tanpa diawasi, pimpinan memberikan kebebasan karyawannya dalam bekerja, karyawan selalu mengembang-kan dan mempertahankan eksistensi perusahaan, menerima resiko dari tindakan yang dilakukan, mengembalikan barang yang dipinjam sesuai dengan kondisi semula. Dimensi kemampuan membuat keputusan dari indikator karyawan dan rekan kerja selalu berdiskusi dalam menyelesaikan masalah pekerjaan, karyawan dan atasan selalu berdiskusi dalam menyelesaikan masalah pekerjaan, karyawan cekatan dalam menjalani tugasnya, karyawan bekerja walau tidak ada perintah, karyawan selalu mengantisipasi adanya masalah dalam bekerja, karyawan bekerja sekreatif mungkin dalam menyelesaikan pekerjaan, adanya kepercayaan terhadap diri sendiri yang melekat, karyawan mampu menentukan dan mengatur prioritas kerja secara efektif, memilih tindakan yang tepat dalam menunjang proses pekerjaan, atasan ikut berpartisipasi dalam penentuan tugas.

Berdasarkan hasil penelitian dari angket yang disebar kepada 45 responden diketahui bahwa kinerja karyawan mencapai skor 17063 dari skor kriterium atau jumlah maksimal perolehan nilai responden terletak pada daerah tinggi yaitu pada interval 3015-21105, sehingga dapat dikatakan bahwa dalam penelitian ini kinerja karyawan telah diaplikasikan dengan baik, namun kinerja karyawan perlu ditingkatkan lagi karena semua dimensi berada dibawah skor ideal.

Aspek kinerja karyawan paling tinggi yaitu terdapat pada dimensi kualitas kerja memperoleh skor sebanyak 3391 atau 83\%, sementara dimensi paling rendah yaitu pada inisiatif memperoleh skor 3002 atau $79 \%$. Secara keseluruhan variabel kinerja karyawan memperoleh skor 17063, apabila di persentasekan kedalam skor ideal maka diperoleh persentase sebesar 80\%, dapat dikatakan menurut Moch. Ali (2013:184) karyawan adalah 21105 untuk 67 item pernyataan. bahwa hampir seluruh responden menyatakan kinerja karyawan dalam kategori tinggi. Skor ideal kinerja.

\section{KESIMPULAN DAN SARAN}

Berdasarkan pembahasan teori, hasil penelitian,pengujian analisis korelasi multipel yang dilakukan mengenai pengaruh disiplin kerja dan keselamatan \& kesehatan kerja (k3) terhadap kinerja karyawan dapat disimpulkan sebagai berikut:

Tingkat disiplin kerja berada pada kategori tinggi. Hal ini dapat dilihat dari dimensi yang tertinggi hingga terendah. Dimensi disiplin kerja yang memiliki penilaian sangat tinggi adalah dimensi taat terhadap aturan perilaku, sedangkan dimensi yang memiliki penilaian yang sangat rendah adalah dimensi taat terhadap peraturan perusahaan. Sehingga dapat disimpulkan bahwa disiplin kerja sebagian besar sudah tinggi.

Gambaran keselamatan dan kesehatan kerja (k3) berada pada kategori cukup tinggi. Hal ini dapat dilihat dari dimensi yang tertinggi. Dimensi ergonomi memiliki penilaian yang sangat tinggi. Sehingga dapat disimpulkan bahwa keselamatan dan kesehatan kerja (k3) sudah cukup tinggi.

Tingkat kinerja karyawan berada pada kategori tinggi. Hal ini dapat dilihat dari dimensi yang tertinggi 
hingga terendah. Dimensi kualitas kerja memiliki penilaian yang sangat tinggi, sedangkan yang terendah yaitu dimensi inisiatif. Sehingga dapat disimpulkan bahwa kinerja sebagian besar sudah tinggi

Berdasarkan hasil penelitian, maka penulis menyarankan beberapa hal mengenai disiplin kerja dan keselamatan \& kesehatan kerja (k3) meningkatkan kinerja karyawan, yaitu sebagai berikut:

Disiplin kerja pada dapat ditingkatkan pada aspek ketaatan pada peraturan. Perusahaan sebaiknya memberikan pengawasan penuh dan ketegasaan pada aturan yang ada di lingkungan perusahaan, serta memberikan sanksi yang dapat membuat karyawan jera agar tidak melakukan pelanggaran yang berulangulang. Ketaatan pada peraturan yang ada di lingkungan merupakan indikator penting dalam meningkatkan hasil dalam mencapai tujuan. Menurut Prawironegoro (2016:118) sasaran disiplin kerja yaitu dengan pembinaan disiplin kerja bertujuan agar dalam diri para karyawan mempunyai rasa disiplin sehingga diharapkan akan mendukung dalam pencapaian tujuan perusahaan atau organisasi.Sehingga bukan hanya dapat memperlancar proses produksi, tetapi mampu memberikan dampak positif bagi setiap karyawan maupun perusahaan.

Keselamatan dan kesehatan kerja (k3) pada cukup tinggi dengan kemampuan ergonomi dapat meningkatkan tingkat keselamatan dan kesehatan terhadap karyawan. Menurut Sedarmayanti (2017:232) tujuan keselamatan dan kesehatan kerja adalah menjamin keadaan, keutuhan dan kesempurnaan, baik jasmani maupun rohani manusia serta karya dan budayanya yang tertuju pada kesejahteraan masyarakat pada umumnya dan manusia pada khususnya. Kemampuan pimpinan dalam memberikan pengarahan tentang keselamatan dan kesehatan kerja (k3) merupakan salah satu untuk peningkatan kompetensi diri karyawan.

Kinerja karyawan pada dapat ditingkatkan melalui kualitas kerja dimana hasil pekerjaan yang karyawan kerjakan memiliki kualitas yang baik. Akan tetapi tingkat inisiatif juga sangat penting dalam meningkatkan kinerja karyawan. Menurut Sedarmayanti (2017:332) sasaran kinerja adalah pernyataan kondisi yang akan ada setelah pekerjaan dilaksanakan, dan yang bisa diukur secara kuantitatif, sasaran kinerja harus sejalan, relavan dan memberi nilai tambah serta harus terikat dan terkait dengan taktik dan tujuan tim, yang merupakan bagian dari langkah pertama model perncanaan kinerja. Pekerjaan yang dilakukan memiliki yang memiliki arti menunjukan bahwa kebermaknaan sebagai arti positif pengembalian penyertaan diri dalam peran kinerja.

\section{DAFTAR PUSTAKA}

Mondy, R. W., \& Martocchio, J. J. (2016). Human
Resource Management (Fourteenth). England: Pearson Education Limited.

Sedermayanti (2017). Manajemen Strategi. Refika Aditama: Jakarta.

Sugiyono, A. (2009). Manajemen Keuangan untuk Praktisi Keuangan. Jakarta: Grasindo.

Sugiyono. (2017). Metode Penelitian Pendidikan (Pendekatan Kuantitatif, Kualitatif, dan R\&D). Bandung: Alfabeta.

Sutrisno, Edy. 2017. Manajemen Sumber Daya Manusia, Cetakan Kelima. Yogyakarta: Prenada Media

Wibowo, 2017. Manajemen Sumber Daya Manusia, Edisi Revisi. Jawa Timur: CV. R.A.De.Rozarie

Widodo (2015). Manajemen Pengembangan Sumber Daya Manusia. Pustaka Pelajar: Jakarta.

Anwar, M., Qadri, M. N., \& Kalsum, U. (2018). Pengaruh Kepemimpinan Transformasional , Disiplin Kerja dan Semangat Kerja terhadap Kinerja Anggota pada Satuan Hubdam VII / Wirabuana. Journal of Economic and Business, 1(79), 46-64.

Aryono, I. A. (2016). Pengaruh Kepemimpinan dan Lingkungan Kerja terhadap Kinerja Karyawan PT

. KAI DAOP 6 Yogyakarta dengan variabel Motivasi sebagai intervening. Journal Ekonomi, $1-30$.

Ayu, K., Sujana, I. N., \& Zukhri, A. (2017). Pengaruh Kompenasi Dan Disiplin Kerja Terhadap Kinerja Karyawan PT Borwita Citra Prima Cabang Singaraja. Journal Pendidikan Ekonomi, 10.

Budiawan, W., Sriyanto, Purwanggono, B., \& Tauhida, D. (2017). Pengembangan Aplikasi Investigasi Kecelakaan Kereta Api Berbasis Web. Prosiding SNATIF, 153-160. https://doi.org/10.2298/PAN0903301G

Heryati, A., \& Menzata, R. A. (2018). Hubungan Antara Pendidikan dan Pelatihan ( Diklat) K3 dan Pemberian kompensasi Terhadap Kinerja Karyawan PT . Kereta Api Indonesia ( Persero ) Devisi Regional III Palembang. Journal Ekonomi Global, 9(1), 71-76.

Ismail, I. (2016). Pengaruh Kelengkapan Alat Kerja Dan Disiplin Kerja Terhadap Kinerja Karyawan. Jurnal Studi Manajemen Dan Bisnis, 3(1), 90101.

Juniarti, N., \& Halin, H. (2017). KINERJA KARYAWAN PT PUTERA SRIWIJAYA MANDIRI. Jurnal Ilmiah Ekonomi Global, 8(02), 111-116.

Mang, L., Mariani, I., \& Sariyathi, N. K. (2017). Pengaruh Motivasi, Komunikasi Dan Disiplin Kerja Terhadap Kinerja Karyawan Warung Mina Peguyangan Di Denpasar. E-Jurnal Manajemen Unud, 6(7), 3540-3569. 
Masharyono, \& Senen, S. H. (2015). Analisis Job Performance Pegawai Honorer Administrasi Dengan Kompetensi Dan Job Characteristics Dalam Mendukung Universitas Pendidikan Indonesia Mencapai Leading And Outstanding. Fokus Ekonomi, 2(10), 120-137.

Munandar, M. R., Astuti, E. S., \& Hakam, M. S. (2014). PENGARUH KESELAMATAN, KESEHATAN KERJA (K3) DAN INSENTIF TERHADAP MOTIVASI DAN KINERJA KARYAWAN (Studi Pada Pekerja bagian Produksi PT. SEKAWAN KARYATAMA MANDIRI Sidoarjo). Jurnal Administrasi Bisnis, 9(1), 1-9.

Muogbo, U. S. (2013). The Impact of Employee Motivation On Organisational Performance ( A Study Of Some Selected Firms In Anambra State Nigeria ) BY. The International Journal of Engineering and Sciences, 2(7), 70-80.

Nuryanti, B. L., Masharyono, M., \& Fauziatunisa, H. (2019). The Effect of Coaching on Employee Performance, 65(Icebef 2018), 136-139. https://doi.org/10.2991/icebef-18.2019.33

Nuryanti, B. L., \& Rahmawati, R. (2016). The Influence of Situational Leadership and Work Environment towards Employees ' Performance, 15, 540-543.

Putri, I., Wahyu, H., \& Reni, D. S. (2013). PENGARUH BUDAYA KERJA, DISIPLIN KERJA DAN K3 TERHADAP KINERJA KARYAWAN TETAP BAGIAN PRODUKSI UNIT SPINNING 2 PADA PT APAC INTI CORPORA. Ilmu Administrasi Bisnis, (024), 11.

S, R. W., \& Panjaitan, T. W. S. (2016). Pengaruh Kebijakan Keselamatan dan Kesehatan Kerja Terhadap Tenaga Kerja Konstruksi PT Wijaya Karya ( Persero ) Tbk . di Proyek Tol Surabaya Mojokerto. Jurnal Titra, 4(2), 273-278.

Senen, S. H., Sumiyati, \& Masharyono. (2016). The Effect of Skill Variety, Task Identity, Task Significance, Autonomy and Feedback on Job Performance, 15, 585-588.

Senen, S. H., \& Triananda, N. (2016). The Employee Performance Influenced by Communication: a Study of BUMD in Indonesia. Advances in Economics, Business and Management Research, 15, 596-598. https://doi.org/10.2991/gcbme16.2016 .111

Suardi, Y., Anton, T., \& Suharsil. (2014). PENGARUH DISIPLIN KERJA, PENDIDIKAN DAN PELATIHAN TERHADAP KINERJA PEGAWAI PADA PT KERTAS KRAFT ACEH (PERSERO. Jurnal Saintikom.

Sugiyono. (2012). Metode Penelitian Kuantutatif Kualitatif dan $R \& D$. Bandung: Alfabeta.

Wairooy, A. (2017). Pengaruh Disiplin Kerja dan Kompensasi Terhadap Kinerja Karyawan pada PT . Pertamina ( Persero ), Tbk . Pemasaran
Region VII Makassar. Jurnal Administrare, 4(1). Winaryo, \& Sunaryo, H. (2016). Pengaruh Disiplin Kerja dan K3 Terhadap Kinerja Karyawan PT Anugerah Putra Siantan Malang. Jurnal Riset Manajemen, 103-117. 